\title{
Late Glacial and Holocene micromammals of northeastern Europe
}

\author{
Dmitry V. Ponomarev, Thijs van Kolfschoten \& Johannes van der Plicht
}

\begin{abstract}
Results of studying micromammalian remains from 15 cave-type localities situated in northeastern Europe are presented. Radiocarbon dating enabled to study the fauna development during six climatic phases: Bølling-Allerød, Younger Dryas, Preboreal, Boreal, Subboreal and Subatlantic. Assemblages of Bølling-Allerød with predominance of Siberian lemming are followed by communities of the Younger Dryas. These are dominated by xerophilous species: narrow-headed vole in the Subpolar Urals, and collared lemming in the rest of region. A considerable proportion of tundra species remained in communities during the Preboreal. A drastic transformation of micromammalian communities from the tundra-steppe to forest has occurred after $9000 \mathrm{BP}$, and possibly before $8500 \mathrm{BP}$. The modern-like fauna was formed during the Subatlantic.
\end{abstract}

KEY WORDS: small mammals, Pleistocene, Holocene, Late Glacial, northeastern Europe.

DmitryV. Ponomarev, [ponomarev@geo.komisc.ru; dvponomarev@inbox.ru], Institute of Geology of the Komi Science Center of the Ural Branch of the Russian Academy of Sciences, Pervomayskay str. 54, Syktyvkar 167982, Komi Republic, Russia; Thijs van Kolfschoten, [t.van.kolfschoten@arch.leidenuniv.nl], Faculty of Archaeology, Leiden University P.O. Box 9515, 2300 RA Leiden, Netherlands; Johannesvan der Plicht, [J.van.der.Plicht@rug.nl], Center for Isotope Research, Groningen University, Nijenborgh 4, 9747 AG Groningen, Netherlands.

\section{Мелкие млекопитающие позднеледниковья и голоцена Европейского Северо-Востока}

\section{Д.В. Пономарев, Т. ван Кольфсхотен, Й. ван дер Плихт}

\begin{abstract}
РЕЗЮМЕ. Представлены результаты изучения микротериофауны из пятнадцати местонахождений пещерного типа северо-востока Европы. Описаны шесть фаз развития микротериофауны СевероВостока Европы, обоснованные радиоуглеродными датировками: бёллинг-аллерёд, поздний дриас, пребореал бореал, суббореал и субатлантика. Ископаемые комплексы бёллинга-аллерёда со значительным участием сибирского лемминга сменяются сообществами позднего дриаса, в которых обильны ксерофильные виды: узкочерепная полевка на Приполярном Урале, а на остальной территории - сообщества с доминированием копытного лемминга. На протяжении пребореала в структуре фауны мелких млекопитающих Приполярного Урала сохраняется значительное участие тундровых видов. Коренная трансформация структуры населения мелких млекопитающих от тундростепных к лесным сообществам произошла после 9000 лет назад и, возможно, до 8500 лет назад. Фауна современного типа сформировалась в субатлантическом периоде.
\end{abstract}

КЛЮЧЕВЫЕ СЛОВА: мелкие млекопитающие, плейстоцен, голоцен, позднеледниковье, СевероВосточная Европа.

\section{Introduction}

Today, the vast area of far northeastern Europe receives a considerable attention of Quaternary paleozoologists. A large volume of data has been available from the Polar Urals (Smirnov et al., 1999; Smirnov \& Golovachov, 1999; Golovachov \& Smirnov, 2009), and the Northern Urals (Guslitser et al., 1990; Kochev, 1993; Smirnov, 1996). In addition, new materials from the Subpolar Urals (Ponomarev, 2005; Ponomarev \& Kryazheva, 2011) and the Timan Ridge (Ponomarev et al., 2005, 2012; Ponomarev, 2006, 2009) are recently presented. A considerable part of these new data (Sokoliny, Schuger 2, 4; Kozhim 1, 2; Pizhma 1, Sed'yu 1 localities) have now been radiocarbon dated in the framework of the research project "COllapse of the
Mammoth Steppe ECosystem" (COMSEC). In this article we review all the available data on fossil mammal faunas of northeastern Europe and analyze the Late Glacial and Holocene dynamics of micro mammalian communities of the entire region. The development of micromammalian assemblages is interpreted in terms of environmental changes.

Time intervals used in this paper $\left({ }^{14} \mathrm{C}\right.$ years $\left.\left.\mathrm{BP}\right): 1\right)$ Bølling-Allerød Interstadial complex (BAIC), 12 700$10950 ; 2)$ Younger Dryas (YD), 10 950-10 150; 3) Preboreal period of the Early Holocene (PB), 10 1509000; 4) Boreal period of the Early Holocene (BO), 9000-8000; 5) Atlantic period of the Middle Holocene (AT), 8000-5000; 6) Subboreal period of the Middle Holocene (SB) 5000-2500, and 7) Subatlantic period of the Late Holocene 2500-200. 


\section{Regional settings}

The northeast of Europe is usually defined as a vast region extending from south to north (from the Severnye Uvaly Ridge, at $60^{\circ} \mathrm{N}$, to the Barents Sea coasts) for about $1000 \mathrm{~km}$, and from the Mezen River in the west to the Urals in the east. According to various sources (Obedkov, 1995; Isachenko, 1964a), the region can be divided into two parts different in relief and geological structure. The eastern mountainous part belongs to the Urals, the remaining area is a part of the Russian Plain including the heavily ruined Timan Ridge.

Modern-day climate is controlled by the near Arctic Ocean. The region is relatively remote from the Atlantic. The climate is strongly influenced by the arctic air masses and by cyclones. A cold temperate (boreal) climate is typical for the largest part of the region; it is characterized by a long and rather severe winter and a short, relatively warm summer (Ovchinnikova, 1964; http://meteo.infospace.ru/climate/html).

The latitudinal change of climatic parameters is gradual, though well observable. During summer the temperature increases from north to south. The mean July temperature is 8 to $10^{\circ} \mathrm{C}$ in Vorkuta and $18^{\circ} \mathrm{C}$ at the southern border. During winter the air temperature depends mostly on heat transport by air masses, and not on insolation, so the temperatures decrease from west to east. The mean January temperature in the western part of the region is about $-15^{\circ} \mathrm{C}$, while in the forelands of the Polar Urals it is $-20^{\circ} \mathrm{C}$. Cold air mass invasions from north and east may result in a temperature drop to $-40^{\circ} \mathrm{C}$ or even to $-50^{\circ} \mathrm{C}$.

The climate of the region is very wet, with annual precipitation exceeding potential evaporation. On the average, the total precipitation in the region is more than $400 \mathrm{~mm}$; on the western slope of the Urals it may be as high as $1000 \mathrm{~mm}$.

The northernmost part of the region lies in the tundra and forest-tundra zones. The rest of the area belongs to the taiga. All the taiga subzones, northern, middle, and southern, are present here. Besides the changes in landscape with latitude, other trends in environmental characteristics may be traced from west to east. The climate becomes more continental and the Siberian biota becomes more abundant (Isachenko, 1964b).

The present-day tundra biome is inhabited by Sicista betulina, Ondatra zibethica, Clethrionomys glareolus (occasionally), Clethrionomys rutilus, Dicrostonyx torquatus, Lemmus sibiricus, Arvicola terrestris, Microtus gregalis, Microtus oeconomus, and Microtus agrestis (in southern part) (Petrov, 2002; Estafyev, 1994). Most numerous in the zone are three species: Dicrostonyx torquatus, Lemmus sibiricus, and Microtus gregalis as follows from the long-term investiga-

Table 1. Frequencies (\%) of micromammal remains from localities in northeastern Europe.

\begin{tabular}{|l|c|c|c|c|c|c|c|c|c|c|c|c|c|}
\hline \multirow{2}{*}{ Species } & \multicolumn{9}{|c|}{ Localities } \\
\cline { 2 - 17 } & 1 & 2 & 3 & 4 & 5 & 6 & 7 & 8 & 9 & 10 & 11 & 12 & 13 \\
\hline Desmana moschata & - & 0.1 & - & - & - & - & - & - & - & - & - & - & - \\
\hline Ochotona pusilla & - & 2.3 & - & 0.1 & - & - & - & - & - & - & - & - & - \\
\hline Pteromys volans & 0.1 & - & - & - & - & - & - & - & - & - & - & - & - \\
\hline Sciurus vulgaris & - & - & 15.7 & - & - & - & - & - & - & 0.7 & - & - & - \\
\hline Tamias sibiricus & 0.1 & - & - & - & - & - & - & - & - & - & - & - & - \\
\hline Sicista sp. & 0.2 & - & - & - & - & - & - & - & - & - & - & - & - \\
\hline $\begin{array}{l}\text { Clethrionomys } \\
\text { rufocanus }\end{array}$ & 8.4 & 1.2 & 22.3 & 0.6 & 2.3 & - & 17.7 & 0.6 & - & 26.5 & 9.9 & - & 9 \\
\hline $\begin{array}{l}\text { Clethrionomys } \\
\text { glareolus }\end{array}$ & - & - & - & - & - & - & - & - & - & - & - & - & 5.3 \\
\hline $\begin{array}{l}\text { Clethrionomys } \\
\text { rutilus }\end{array}$ & - & - & - & - & - & - & - & - & - & - & - & - & 5.1 \\
\hline $\begin{array}{l}\text { Clethrionomys } \text { ex } \\
\text { gr. rutilus-glareolus }\end{array}$ & 78.2 & 5.1 & 19.6 & 0.2 & 8 & 61 & 15.6 & 0.6 & - & 36.1 & 10.4 & 9.7 & - \\
\hline Dicrostonyx sp. & - & 2.2 & 0.6 & 43.1 & 14.9 & 1.7 & 4.1 & 56.4 & 45.6 & 0.4 & 5.4 & 12.4 & 5.1 \\
\hline Lemmus sibiricus & - & 55.7 & - & 17.3 & 19.5 & & 4.1 & 21.2 & 35.9 & - & 14.6 & 38.9 & 11 \\
\hline $\begin{array}{l}\text { Myopus } \\
\text { schisticolor }\end{array}$ & 3.9 & 0.5 & 7.7 & 2.1 & 12.6 & 6.8 & 8.8 & 6.7 & - & 5.7 & 3.8 & & 5.1 \\
\hline Arvicola terrestris & 0.1 & 8.9 & 7.6 & 0.2 & 1.1 & 1.7 & 12.9 & 1.7 & - & 2.6 & 0.1 & 1.8 & 14.8 \\
\hline Microtus gregalis & - & 9.1 & - & 35.6 & 16.1 & 3.4 & 2 & 10.6 & 18.5 & 0.3 & 33.9 & 33.6 & 21.7 \\
\hline $\begin{array}{l}\text { Microtus } \\
\text { oeconomus }\end{array}$ & 4.9 & 9.8 & 18.9 & 0.4 & 1.1 & 20.3 & 32 & 1 & - & 5.3 & 10.4 & - & 13.7 \\
\hline Microtus agrestis & 4.2 & 3.4 & 7.7 & 0.4 & 10.3 & 5.1 & 2.0 & 0.6 & - & 19.6 & 7.5 & 3.5 & 9.2 \\
\hline $\begin{array}{l}\text { Microtus } \\
\text { middendorffii }\end{array}$ & - & 1.7 & - & - & 13.8 & - & 0.7 & 0.6 & - & 2.8 & 3.8 & - & - \\
\hline Number of remains & 1213 & 1557 & 700 & 3294 & & & 170 & 177 & 195 & 2460 & 704 & & 358 \\
\hline
\end{tabular}


Table 1 (continued).

\begin{tabular}{|c|c|c|c|c|c|c|c|c|c|c|c|c|c|}
\hline \multirow{2}{*}{ Species } & \multicolumn{13}{|c|}{ Localities } \\
\hline & 14 & 15 & 16 & 17 & 18 & 19 & 20 & 21 & 22 & 23 & 24 & 25 & 26 \\
\hline $\begin{array}{l}\text { Desmana } \\
\text { moschata }\end{array}$ & - & - & - & - & - & - & - & - & - & - & - & - & - \\
\hline Ochotona pusilla & - & - & 1 & 1.7 & - & - & - & 0.1 & - & - & - & - & - \\
\hline Pteromys volans & - & - & - & - & - & - & - & - & - & - & - & - & - \\
\hline Sciurus vulgaris & 11.6 & - & - & - & 2.7 & 0.5 & 1.8 & - & 0.5 & - & - & 29.3 & 16.5 \\
\hline Tamias sibiricus & - & - & - & - & - & - & - & - & - & - & - & - & - \\
\hline Sicista $\mathrm{sp}$. & - & - & - & - & - & - & - & - & 1 & - & - & - & - \\
\hline $\begin{array}{l}\text { Clethrionomys } \\
\text { rufocanus }\end{array}$ & 15.7 & 4.6 & 0.8 & - & 19.8 & 23 & 6.5 & 1.7 & 6.2 & 7 & 1.32 & 8 & 10.3 \\
\hline $\begin{array}{l}\text { Clethrionomys } \\
\text { glareolus }\end{array}$ & 4.7 & 2.6 & 0.7 & - & 10 & 4 & 7.3 & 0.9 & 6.7 & 13 & - & - & - \\
\hline $\begin{array}{l}\text { Clethrionomys } \\
\text { rutilus }\end{array}$ & 5.6 & 6.2 & 1.2 & - & 18.9 & 14.6 & 8.9 & 2.9 & 11.4 & 19.5 & - & - & - \\
\hline $\begin{array}{l}\text { Clethrionomys ex } \\
\text { gr. rutilus- } \\
\text { glareolus }\end{array}$ & - & - & - & - & - & - & - & - & - & - & 1.99 & 12 & 5.2 \\
\hline Dicrostonyx sp. & - & 13.9 & 15.8 & 15.7 & - & 2.2 & 1.5 & 12.8 & - & - & 17.88 & - & - \\
\hline Lemmus sibiricus & 3.7 & 24.2 & 36.2 & 43.3 & - & 6.2 & 2.8 & 10.3 & 1.6 & 5 & 27.81 & - & - \\
\hline $\begin{array}{l}\text { Myopus } \\
\text { schisticolor }\end{array}$ & 5.7 & 5.4 & 6.4 & 4.4 & 31.5 & 12.4 & 6 & 1.6 & 5 & 2.9 & 3.97 & 13.3 & 8.2 \\
\hline $\begin{array}{l}\text { Arvicola } \\
\text { terrestris }\end{array}$ & 41 & 7.6 & 1.8 & 1 & 7.4 & 15.9 & 38.7 & 30.6 & 12.3 & 29.3 & 1.0 & 10.7 & 46.4 \\
\hline Microtus gregalis & 1.8 & 18.9 & 25.3 & 29.3 & - & 4 & 6 & 12.3 & 1 & 2.7 & 32.5 & - & - \\
\hline $\begin{array}{l}\text { Microtus } \\
\text { oeconomus }\end{array}$ & 3.7 & 7.4 & 3.6 & 2.2 & 1.8 & 8.8 & 9.8 & 16.3 & 12.1 & 5 & 6.5 & 14.7 & 8.2 \\
\hline Microtus agrestis & 6.5 & 9.2 & 7.2 & 1.2 & 7.9 & 8.4 & 10.7 & 10.5 & 42.2 & 15.6 & 7.0 & 10.7 & 2.1 \\
\hline $\begin{array}{l}\text { Microtus } \\
\text { middendorffii }\end{array}$ & - & & - & - & - & - & - & - & - & & - & - & - \\
\hline $\begin{array}{l}\text { Number of } \\
\text { remains }\end{array}$ & 1415 & 1680 & 2634 & 337 & 111 & 226 & 214 & 1611 & 684 & 481 & & $75^{*}$ & $97 *$ \\
\hline
\end{tabular}

Localities: 1 - Sed'yu 2, layer 1 (Ponomarev, 2006; Ponomarev et al., 2012); 2 - Sed'yu 1 (Ponomarev, 2006; Ponomarev et al., 2012); 3 - Pizhma 1, layer 2 (Ponomarev et al., 2005, 2012); 4 - Pizhma 1, layer 5 (Ponomarev et al., 2005, 2012); 5 - Zveroboy, layer 1 (Smirnov et al., 1999); 6 - Zveroboy, layer 1 (Smirnov et al., 1999); 7 - Pymvashor, layer 3 (Smirnov et al., 1999); 8 - Pymvashor, layer 4 (Smirnov et al., 1999); 9 - Pymvashor, layer 5 (Smirnov et al., 1999); 10 - Sokoliny, layer 1 (Ponomarev, 2005 ); 11 -Sokoliny, layer 2 (Ponomarev, 2005); 12 - Sokoliny, layer 3 (Ponomarev, 2005); 13 - Schuger 1, layer 2 (Ponomarev \& Kryazheva, 2011 ); 14 Schuger 2 (Ponomarev \& Kryazheva, 2011); 15 - Schuger 4, layer 1 (Ponomarev \& Kryazheva, 2011); 16 - Schuger 4, layer 2 (Ponomarev \& Kryazheva, 2011); 17 - Schuger 4, layer 3 (Ponomarev \& Kryazheva, 2011); 18 -Schuger 5, layer 1 (Ponomarev \& Kryazheva, 2011); 19 - Schuger 5, layer 2 (Ponomarev \& Kryazheva, 2011); 20 - Kozhim 1, layer 1; 21 — Kozhim 1, layer 2; 22 — Kozhim 2, layer 1; 23 - Kozhim 2, layer 2; 24 - Medvezh'ya, brown loam A (Kochev, 1993; Smirnov, 1996); 25 — Shezhim (Smirnov \& Sadykova, 2003); 26 - Pikhtovka (Smirnov \& Sadykova, 2003).

* - maximum number of the same molar.

tions using trapping techniques (Petrov, 2002) and also from the analysis of rough-legged buzzard Buteo lagopus pellets and polar fox Vulpes lagopus faeces (Voronin, 1995; Polezhaev, 1998).

The forest-tundra is presently occupied by Sciurus vulgaris (occasionally), Sicista betulina, Ondatra zibethica, Clethrionomys rufocanus (mainly in mountainous part), Clethrionomys rutilus, Lemmus sibiricus, Arvicola terrestris, Microtus gregalis, Microtus oeconomus and Microtus agrestis.

The taiga biome is inhabited by Ochotona hyperborea (in the mountainous part only), Sciurus vulgaris, Tamias sibiricus, Sicista betulina, Micromys minutus, Ondatra zibethica, Clethrionomys rufocanus (mainly in mountainous regions), Clethrionomys glareolus, Clethrionomys rutilus, Myopus schisticolor, Arvicola terrestris, Microtus oeconomus and Microtus agrestis (Bobretsov et al., 2005; Kulik, 1972; Petrov \& Poroshin, 2005; Turyeva \& Balibasov, 1982; Turyeva et al., 1977; Bobretsov et al., 2004).

\section{Material and methods}

Twenty six local faunas of small mammals have been studied. The results are shown in Table 1 and in Figure 1. Radiocarbon dates obtained for faunal assemblages are listed in Table 2. The local fauna is a list of taxa recovered from one layer or several conventional 


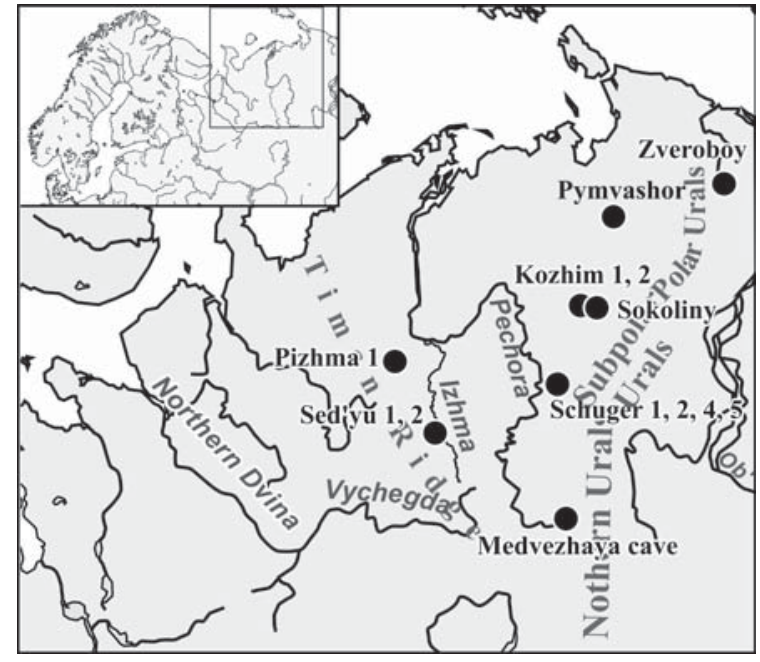

Figure 1. Map of micromammalian localities in northeastern Europe.

horizons (Smirnov, 2003). All the local faunas are recovered from localities of a single taphonomic type, namely zoogenic deposits in karst caverns. Fossil remains accumulated as a result of hunting activities of predators and raptors.

All studied localities can be combined into four geographical groups: localities of the Southern and Middle Timan Ridge (Sed'yu 1, 2 and Pizhma 1 respectively), sites of the Northern Urals (Medvezh'ya Cave, Shezhym, Pikhtovka), localities of the Subpolar Urals (Sokoliny, Schuger 1, 2, 4, 5; Kozhim 1, 2), and the Polar Urals (Pymvashor and Zveroboy).

The ${ }^{14} \mathrm{C}$ dates were calibrated using IntCal09 calibration curve (Reimer et al., 2009). The calibrated

Table 2. Radiocarbon dates for Quaternary mammal remains from localities in northeastern Europe.

\begin{tabular}{|c|c|c|c|c|c|c|c|}
\hline Sites & $\begin{array}{l}{ }^{14} \mathrm{C} \\
\text { date } \\
(\mathrm{BP})\end{array}$ & $\begin{array}{c}1- \\
\text { sigma }\end{array}$ & Lab. No * & Species & $\begin{array}{l}\text { Dated } \\
\text { object }\end{array}$ & $\begin{array}{l}\text { cal BP range } \\
\text { (1-sigma) }\end{array}$ & Reference \\
\hline $\begin{array}{l}\text { Medvezh'ya Cave } \\
\text { (brown "A" loam) }\end{array}$ & 13260 & 230 & $\mathrm{~T}-13476$ & $\begin{array}{c}\text { mamm. } \\
\text { indet }\end{array}$ & bone & $16670-15650$ & $\begin{array}{c}\text { Guslitser \& } \\
\text { Pavlov, } 1988 \\
\end{array}$ \\
\hline $\begin{array}{l}\text { Medvezh'ya Cave } \\
\text { (brown “A” loam) }\end{array}$ & 12230 & 100 & LE-3059 & $\begin{array}{c}\text { mamm. } \\
\text { indet }\end{array}$ & bone & $14210-13930$ & $\begin{array}{c}\text { Guslitser \& } \\
\text { Pavlov, } 1988 \\
\end{array}$ \\
\hline $\begin{array}{c}\text { Pymvashor } \\
\text { (layer 3) }\end{array}$ & 8500 & 250 & GIN-9005 & $\begin{array}{l}\text { mamm. } \\
\text { indet }\end{array}$ & bone & $9890-9130$ & $\begin{array}{l}\text { Golovachov \& } \\
\text { Smirnov, } 2009 \\
\end{array}$ \\
\hline $\begin{array}{c}\text { Pymvashor } \\
\text { (layer 4) }\end{array}$ & 10000 & 250 & GIN-9004 & $\begin{array}{l}\text { mamm. } \\
\text { indet }\end{array}$ & bone & $11990-11210$ & $\begin{array}{l}\text { Golovachov \& } \\
\text { Smirnov, } 2009 \\
\end{array}$ \\
\hline $\begin{array}{c}\text { Pymvashor } \\
\text { (layer 5) }\end{array}$ & 11125 & 80 & TUa-1394 & $\begin{array}{l}\text { mamm. } \\
\text { indet }\end{array}$ & bone & $13110-12930$ & $\begin{array}{l}\text { Golovachov \& } \\
\text { Smirnov, } 2009\end{array}$ \\
\hline $\begin{array}{c}\text { Pizhma } 1 \\
\text { (layer 5) }\end{array}$ & 9940 & 150 & GIN-10570 & $\begin{array}{c}\text { mamm. } \\
\text { indet }\end{array}$ & bone & $11700-11220$ & $\begin{array}{c}\text { Ponomarev et } \\
\text { al., } 2005\end{array}$ \\
\hline $\begin{array}{c}\text { Pizhma } 1 \\
\text { (layer 5) }\end{array}$ & 10180 & 50 & GrA-42216 & $\begin{array}{l}\text { Alopex } \\
\text { lagopus }\end{array}$ & calcaneus & $11980-11470$ & $\begin{array}{c}\text { Ponomarev et } \\
\text { al., } 2012\end{array}$ \\
\hline Sed'yu 1 & 10560 & 280 & $\begin{array}{l}\text { IGAN- } \\
3224 \\
\end{array}$ & $\begin{array}{c}\text { mamm. } \\
\text { indet }\end{array}$ & bone & $12725-11985$ & $\begin{array}{c}\text { Ponomarev, } \\
2006 \\
\end{array}$ \\
\hline Sed'yu 1 & 12310 & 60 & GrA-38567 & $\begin{array}{l}\text { Desmana } \\
\text { moschata }\end{array}$ & mandible & $\begin{array}{l}14460-14360 \\
14240-14050 \\
\end{array}$ & $\begin{array}{c}\text { Ponomarev et } \\
\text { al., } 2012 \\
\end{array}$ \\
\hline Sokoliny, layer 2 & 10390 & 50 & GrA-42215 & Lemmus & mandible & $12390-12140$ & - \\
\hline Schuger 4 , layer 1 & 10090 & 60 & GrA-49440 & $\begin{array}{l}\text { Dicro- } \\
\text { stonyx }\end{array}$ & bone & $11820-11900$ & $\begin{array}{c}\text { Ponomarev \& } \\
\text { Kryazheva, } \\
2011\end{array}$ \\
\hline Schuger 4 , layer 2 & 9710 & 45 & GrA-49351 & $\begin{array}{l}\text { Rangifer } \\
\text { tarandus }\end{array}$ & humerus & $11205-11125$ & $\begin{array}{c}\text { Ponomarev \& } \\
\text { Kryazheva, } \\
2011\end{array}$ \\
\hline Schuger 4 , layer 3 & 11850 & 60 & GrA-49439 & Lemmus & cranium & $13800-13620$ & $\begin{array}{c}\text { Ponomarev \& } \\
\text { Kryazheva, } \\
2011\end{array}$ \\
\hline Schuger 2 & 950 & 35 & GrA-49352 & $\begin{array}{l}\text { Sciurus } \\
\text { vulgaris }\end{array}$ & mandible & $870-825$ & $\begin{array}{c}\text { Ponomarev \& } \\
\text { Kryazheva, } \\
2011\end{array}$ \\
\hline Kozhim 1, layer 2 & 9090 & 45 & GrA-49353 & $\begin{array}{l}\text { Arvicola } \\
\text { terrestris }\end{array}$ & mandible & $10260-10205$ & - \\
\hline Kozhim 2, layer 2 & 1655 & 35 & GrA-49355 & $\begin{array}{l}\text { Arvicola } \\
\text { terrestris }\end{array}$ & mandible & $1605-1520$ & - \\
\hline Zveroboy, layer 4 & 4100 & 200 & GIN-9006 & $\begin{array}{c}\text { mamm. } \\
\text { indet }\end{array}$ & bone & $4860-4380$ & $\begin{array}{l}\text { Golovachov \& } \\
\text { Smirnov, } 2009 \\
\end{array}$ \\
\hline
\end{tabular}

" Laboratory codes for dates: CAMS — Centre for Accelerator Mass Spectrometry, Lawrence Livermore National Laboratory, USA; GIN — Geological Institute, Russian Academy of Sciences (RAS), Russia; GrA — Groningen Radiocarbon Laboratory, The Netherlands; LE - Institute of Archeology, Leningrad Branch (currently Institute of the History of Material Culture), RAS, Russia; T - Trondheim, Radiological Dating Laboratory, Norway; TUa - prepared in Trondheim, measured in Uppsala University, Sweden. 
dates are reported in calBP, i.e. calendar years relative to the year 1950 .

To describe distinctive features of ecological structure dynamics in detail it is necessary to classify small mammal species according to their biological and ecological requirements: biotopes, climatic preference (temperature and humidity) and distribution in modern biomes. This information is taken from the literature (Ognev, 1950; Gromov \& Polyakov, 1977; Gromov \& Erbayeva, 1995; Anufriev, 1994a, b, c; Petrov, 1994a, b, c; Pystin, 1994; and others).

According to the main climatic factors (temperature and humidity), micromammalian species are combined in the following way: 1) cryoxerophilous species: collared lemming (Dicrostonyx);2) mesothermic-xerophilous: narrow-headed vole (Microtus gregalis); 2) mesophilous species preferring temperate conditions: Clethrionomys species and field vole (Microtus agrestis); 3) mesothermic-hydrophilous species: root vole (Microtus oeconomus) and wood lemming (Myopus schisticolor); 4) eurythermic-hydrophilous species: water vole (Arvicola terrestris); 5) cryohydrophilous species: Siberian brown lemming (Lemmus sibiricus) and Middendorf's vole (Microtus middendorffii).

One of the most significant ecological parameters is the specific biotope. Small mammals prefer certain biotopes, and can therefore be divided into four groups: 1) typical tundra biotopes except for wet habitats collared lemming (Dicrostonyx torquatus) and (partly) narrow-headed vole (Microtus gregalis) which is also abundant in grasslands, shrubs and floodplains; 2) wet tundra biotopes - Siberian brown lemming (Lemmus sibiricus) and Middendorf's vole (Microtus middendorffii); 3) riparian habitats - water vole (Arvicola terrestris). The water vole Arvicola terrestris prefers the riparian habitats mainly in summer whereas in wintertime it occupies elevated areas far from water bodies. To some extent, the root vole (Microtus oecono$m u s$ ) can be assigned to this group as well. But it prefers shrubby highly productive lush riparian vegetation along shores of small rivers and springs; 4) all kind of forest habitats - all Clethrionomys voles; 5) various forest and grassland habitats — field vole (Microtus agrestis). In the tundra, this species inhabits patches of willow trees in shrub tundra and on floodplains.

According to their distribution in modern biomes, the species are combined into five groups: 1) typical steppe species - steppe pika (Ochotona pusilla); 2) typical taiga species — wood lemming, Clethrionomys species and field vole; 3 ) typical tundra species collared lemming, Siberian brown lemming, Middendorf's vole; 4) typical for two biomes: tundra and steppe - narrow-headed vole; 5) typical for several biomes - root vole and water vole. It is noteworthy that among modern non-tundra species the northern red-backed vole (Clethrionomys rutilus), root vole, field vole, and the water vole range farthest north up to the northern border of the shrub tundra. They are abundant there.

\section{Results and discussion}

\section{Bølling-Allerød interstadial complex}

Fossil assemblages of the BAIC are known from different parts of the region. The unique feature of the Bølling-Allerød fauna is its moderate cryohydrophilous nature. It is characterized by a high amount of Siberian lemming remains in comparison with other tundra species. Such an ecological structure is observed in Schuger 4, layer 2 and 3; Medvezh'ya Cave, brown loam A; Sed'yu 1 and Pymvashor, layer 5. The fossil assemblage from the brown loam $\mathrm{A}$ is a little older than the BAIC, the end of the Late Glacial Transition as appears from one of the dates (13260 BP) obtained for this layer. The mammal communities from Schuger 4 and Medvezh'ya Cave are very similar in species composition and ecological structure, but the fauna from Pymvashor is more adapted to colder climate. This is explained by its location, the north of the region. Possibly the local fauna of Sokoliny, layer 3 is also of BAIC age because layer 3 underlies a layer 2 which is radiocarbon dated to the Younger Dryas, and because the mammal assemblage of layer 3 is much like the community of the Medvezh'ya Cave. A considerable proportion of Siberian lemming remains is also observed for this fauna and apparently it dates to one of the Late Glacial episodes, of which the BAIC is the most likely one.

The fauna recovered from Sed'yu 1 locality is markedly different. Remains of Siberian lemming far exceed all other species in abundance $(61.5 \%)$. Specific features of this assemblage resulted from specific natural environments and floristic associations as well as taphonomical factors. This fossil assemblage represents an extreme type of community with a clear predominance of cryohydrophilous species - the Siberian lemming. Analogues of this fauna can be found among modern communities inhabiting the arctic tundra (Petrov, 2002). A very similar assemblage is also known from layer 4 of Studyonaya Cave in the Northern Urals (Kochev, 1993). This layer underlies the layers 1 and 2 with predominance of collared lemming remains that allowed Smirnov (1996) to suggest that these layers are of LGM age, and that layer 4 dates to the Early-Middle Weichselian.

According to palynological data (Simakova \& Puzachenko, 2008a; Nikiforova, 1982; Arslanov et al., 1981; Velichko et al., 1997, 2002; Grichuk, 1982; and others), the north of Eastern Europe was dominated by shrub tundra and periglacial forest-tundra, with local patches of tundra-steppe. Most common were communities with Betula nana, Salix, Ericales, Hippophae rhamnoides, Juniperus, Rubus, Helianthemum, Armeria, Sphagnum, Selaginella, along with pine-birch stands.

Wood macrofossils and palynological data on treeline dynamics during Late Glacial and Holocene according to materials from the north of Europe (Latalowa \& van der Knaap, 2006), central and northwestern 


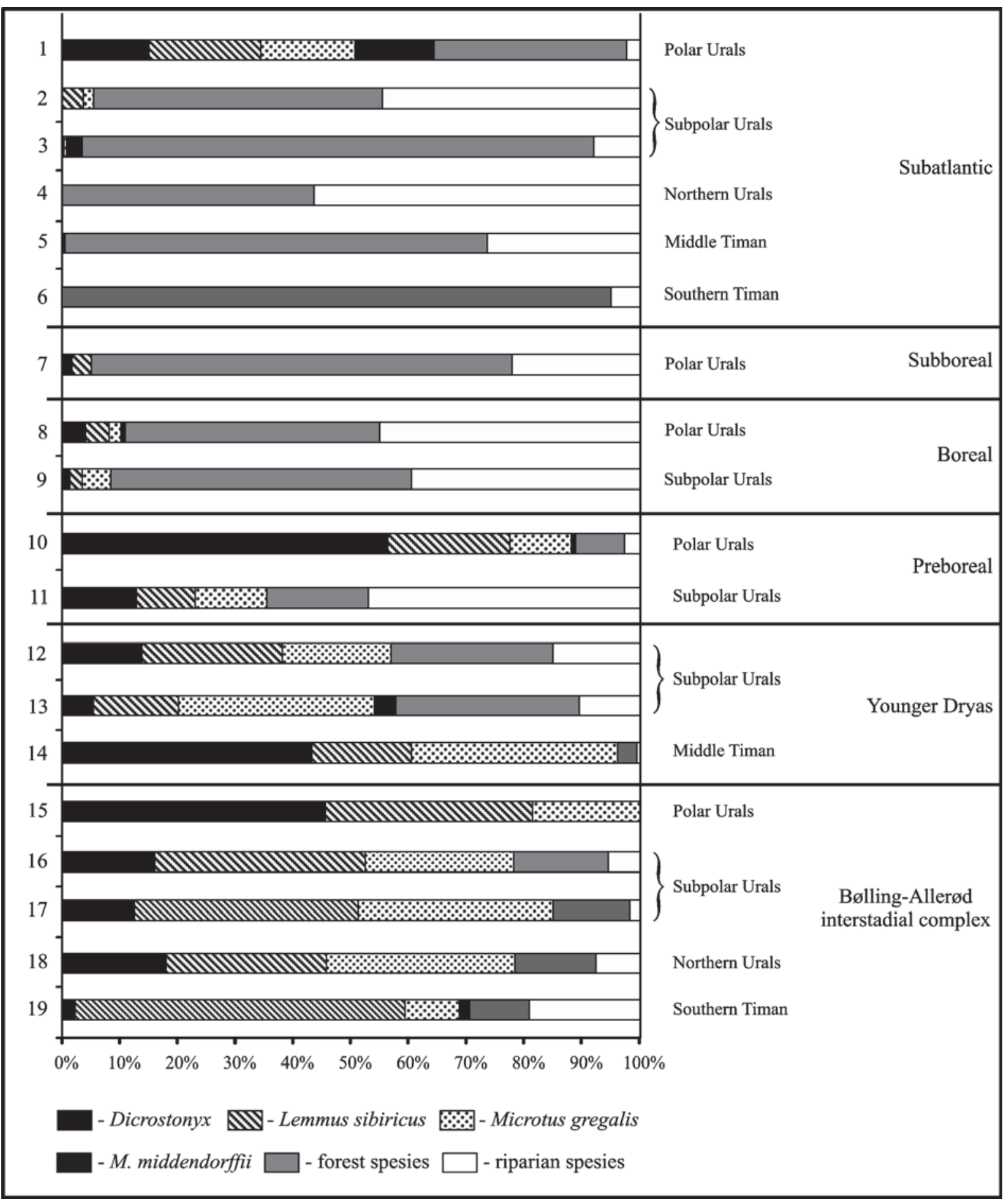

Figure 2. Abundance of rodents (\%) in fossil assemblages. 1 - Zveroboy, layer 1;2 - Schuger 2; 3 - Sokoliny, layer 1; 4 Pikhtovka; 5 - Pizhma 1, layer 2; 6 - Sed'yu 2, layer 1; 7 - Zveroboy, layer 4; 8 - Pymvashor, layer 3; 9 - Kozhim 1, layer 1; 10 - Pymvashor, layer 4; 11 - Kozhim 1, layer 2; 12 - Schuger 4, layer 1; 13 - Sokoliny, layer 2; 14 - Pizhma 1, layer 5; 15 - Pymvashor, layer 5; 16 - Schuger 4, layer 2; 17 - Sokoliny, layer 3; 18 - Medvezh'ya Cave, brown loam A; 19 - Sed'yu 1.

parts of East European Plain (Novenko et al., 2009), north of Eurasia (Binney et al., 2009), Scandinavia (Kullman, 2008) and Karelia (Wolhfarth et al., 2007) support the conclusions concerning a noticeable pres- ence of trees in BAIC vegetation of northern Europe especially in river valleys and protected biotopes.

Earlier suggestions that trees in the European northeast reached far north, even up to the coast of the 
Barents Sea (Nikiforova, 1982; Arslanov et al., 1981), are not supported by more recent research near the coasts of the Barents Sea (Paus et al., 2003) and the Kara Sea (Andreev et al., 2001). According to these data, shrub tundra (Paus et al., 2003) associations with Poaceae, Cyperaceae, Salix, Saxifraga and xerophytes (Andreev et al., 2001) grew there, and the reconstructed temperature was slightly colder than the present one.

\section{Younger Dryas}

The local faunas from Schuger 4, layer 1, Sokoliny, layer 2 and Pizhma 1, layer 5 represent the Younger Dryas micromammalian fauna. We attribute the age of layer 1 to the Younger Dryas because it is consistent with the calibrated radiocarbon date of this interval (11820-11900 calBP) and which is within the chronological limits of the Younger Dryas as observed by Rasmussen et al. (2006).

Younger Dryas communities of micromammals are considerably different from each other. In the Timan Ridge (Pizhma 1, layer 5) a large fraction of all the remains (almost 96\%) shows three species, namely collared lemming (46.4\%), Siberian lemming (18.6\%) and narrow-headed vole $(30.7 \%)$. Assemblages less adapted to cold inhabited the Subpolar Urals at this time, with more than half of the remains of tundra species. Either the three tundra species (Schuger 4, layer 1), or narrow-headed vole (Sokoliny, layer 2) predominate. Probably the resemblance of all assemblages from the Subpolar Urals is not coincidental, but is a result of specific local environments of this area during Younger Dryas.

As follows from palynological data, the Younger Dryas cooling caused birch forests to be more open, while tundra and steppe plant communities penetrated into free areas (Arslanov et al., 1981; Nikiforova, 1982; Velichko et al., 1997; Kremenetski et al., 1998; Kaakinen \& Eronen, 2000; Velichko et al., 2002; Bohncke, 2008; Golubeva, 2008; and others). Shrub tundra and larch-pine-birch woodlands developed along with steppe communities.

\section{Preboreal}

Fossil assemblages dating to the Preboreal are found in Pymvashor, layer 4 and Kozhim 1, layer 2. The community of Pymvashor is quite cold-adapted (81\% of tundra species) and has much in common with the assemblage from layer 5 of Pizhma 1. Such an appearance of this local fauna, predominance of cryophilous species, is explained by the northern geographical position of the locality. The mammalian assemblage of Kozhim 1 is a typical "hyperborean", "tundra-steppe", "non-analogue" with considerable amounts of tundra species (35\% altogether) and a low share of taiga species (17.6\%).

During the Preboreal, shrub tundra was succeeded by forest-tundra floristic associations; locally there existed pine-birch forests, sometimes with spruce, alternating with tundra-steppe communities. It should be noted that in the north of Eastern Europe floristic ele- ments of periglacial tundra-steppe persisted in the vegetation until the Boreal (Arslanov et al., 1981; Nikiforova, 1982; Velichko et al., 1997; Kremenetsky et al., 1998; Kaakinen \& Eronen, 2000; Velichko et al., 2002; Golubeva, 2008; Simakova \& Puzachenko, 2008b; and others).

The paleoclimatic data obtained for the Subpolar Urals must be mentioned. It has been shown by Kultti et al. (2003) that the Postglacial climatic optimum occurred here during the early Holocene (9500-9000 BP) when summer temperatures were $2{ }^{\circ} \mathrm{C}$ warmer than today, and the climate was generally more humid. This warming was accompanied by expansion of forest vegetation and lasted until 5500-4500 BP.

\section{Boreal}

The Boreal fauna is observed in layer 3 of Pymvashor and possibly in layer 1 of Kozhim 1 . The Pymvashor assemblage is typically forest type with dominant forest and riparian species. The proportion of tundra dwellers is insignificant. Layer 1 of Kozhim 1 overlies layer 2, which is radiocarbon dated to the Preboreal. Forest and riparian species (90\%) prevail in the community of layer 1 .

During the Boreal period taiga forests became the prevalent vegetation type; they expanded northwards as far as the Arctic sea coasts (Arslanov et al., 1981; Nikiforova, 1982; Velichko et al., 1997; Kremenetsky et al., 1998; Kaakinen \& Eronen, 2000; Velichko et al., 2002; Golubeva, 2008; Simakova \& Puzachenko, 2008a; and others).

\section{Subboreal}

The Subboreal assemblage was recovered from cave deposits of the layer 4 of Zveroboy. The fauna is dominated by forest (more than 50\%) and riparian (about $30 \%$ ) species but tundra species are present in much smaller amounts.

One more climatic optimum has been recorded in the Subboreal; at that time dark coniferous forests with participation of broadleaf trees spread over the greater part of the territory. The southern taiga subzone reached as far as $64-65^{\circ} \mathrm{N}$, and northern taiga expanded onto the coasts of the Barents Sea. In the southernmost areas there were subtaiga forests of broadleaf species (Surova et al., 1975; Arslanov et al., 1981; Nikiforova, 1982; Velichko et al., 1997; Kremenetsky et al., 1998; Kaakinen \& Eronen, 2000; Velichko et al., 2002; Golubeva, 2008).

\section{Subatlantic}

The forest assemblages from Schuger 2, Kozhim 2, layer 2 of Pizhma 1, Sed'yu 2, layer 1 of Schuger 5, layer 1 of Zveroboy, Pikhtovka, and Shezhim are of Subatlantic age. The species composition and ecological structure of micromammalian fauna in different parts of the region is essentially variable. The forest species predominate in assemblages of the taiga zone of the Timan Ridge and the Northern Urals. To the north in the Subpolar Urals tundra species collared lemming 
and narrow-headed vole appear, but the forest species remain dominant. The late Holocene fauna of the Polar Urals is tundra-like; tundra species dominate while taiga and riparian dwellers are considerably less numerous.

The climate underwent several cooling and warming phases in the region during the Subatlantic (Nikiforova, 1982; Golubeva, 2008).

\section{Conclusion}

We conclude that the evolution of the micromammalian fauna in northeastern Europe took place as follows. The Bølling-Allerød warming led to a wide distribution of communities with predominance of Siberian lemming (cryohydrophilous species) in the entire European northeast, with an exception of its northernmost part. The cooling during the Younger Dryas in the Subpolar Urals resulted in a reduction of tundra species and an increase of forest species. Among tundra forms, the xerophilous narrow-headed vole becomes more numerous. It should be also noted that the Younger Dryas fossil assemblages of the Subpolar Urals show a higher content of steppe elements, in contrast with other communities of that time. The assemblages of Timan (Pizhma 1) and the Polar Urals (Pumvashor) are comprised of more cryophilous species, with a considerable portion of tundra species and predominance of collared lemming. The peculiarity of fossil assemblages of the Subpolar Urals is probably not coincidental and reflects not yet known specific landscape-climate features of this area during the Younger Dryas.

The Preboreal warming resulted in a lower proportion of tundra species and a synchronous increase of riparian species. However, the fauna appearance in general remained mixed tundra-steppe, in contrast with climate reconstructions showing that at $9000 \mathrm{BP}$, most part of the region has been occupied by taiga. This persisting tundra-steppe structure might contribute to variability of habitats typical for mountainous areas and also by the prolonged existence of periglacial vegetation until the Boreal. Radical transformation of micromammalian communities resulted in replacing dominant species from tundra to forest occurred after 9000 $\mathrm{BP}$, and possibly before $8500 \mathrm{BP}$. Forest species remained in the fauna in the north of region till the end of the Subboreal. The modern fauna was formed during the Subatlantic.

ACKNOWLEDGEMENTS. The work was supported by the Netherlands Organisation for Scientific Research (NWO), grant \# 47.009.004, by NWO-RFBR, grant \# 07-05-92312, RFBR grant \# 12-04-00165. We are grateful to two anonymous reviewers for their valuable comments.

\section{References}

Andreev A., Manley W., Ingólfsson Ó. \& Forman S. 2001. Environmental changes on Yugorski Peninsula, Kara
Sea, Russia, during the last 12,800 radiocarbon years // Global and Planetary Change. Vol.31. P.255-264.

Anufriev V.M. 1994a. [Bank vole] // Estafyev A.A. (ed.). [Fauna of European North-East of Russia. Mammals. Vol.2. Part 1]. Sankt-Peterburg: Nauka. P.173-185 [in Russian].

Anufriev V.M. 1994b. [Root vole] // Estafyev A.A. (ed.). [Fauna of European North-East of Russia. Mammals. Vol.2. Part 1]. Sankt-Peterburg: Nauka. P.242-251 [in Russian].

Anufriev V.M. 1994c. [Field vole] // Estafyev A.A. (ed.). [Fauna of European North-East of Russia. Mammals. Vol.2. Part 1]. Sankt-Peterburg: Nauka. P.252-262 [in Russian].

Arslanov H.A., Lavrov A.S. \& Nikiforova L.D. 1981. [About stratigraphy, geochronology and climate changes in the Late Pleistocene and Holocene of the north-east of the Russian Plain] // Velichko A.A. \& Faustova M.A. (eds.). Pleistotsenovye Oledeneniya Vostochno-Evropeiskoyi Ravniny. Moskva: Nauka. P.37-52 [in Russian].

Binney H., Willis K., Edwards M., Bhagwat S., Anderson P., Andreev A., Blaauw M., Damblon F., Haesaerts P., Kienast F., Kremenetski K., Krivonogov S., Lozhkin A., MacDonald G., Novenko E., Oksanen P., Sapelko T., Valiranta M. \& Vazhenina L. 2009. The distribution of late-Quaternary woody taxa in northern Eurasia: evidence from a new macrofossil database // Quaternary Science Reviews. Vol.28. P.2445-2464.

Bobretsov A.V., Lukyanova L.E. \& Poroshin E.A. 2005. [Structure and dynamics of small mammals population of the northern Urals foothills] // Trudy Komi Nautchnogo Tsentra UrO RAN, Syktyvkar. P.5-20 [in Russian].

Bobretsov A.V., Neifeld N.D., Sokolsky S.M., Teplov V.V. \& Teplova V.P. 2004. [Mammals of Pechora-Ilych Nature Reserve]. Syktyvkar: Komi knizhnoe izdatel'stvo. 464p. [in Russian]

Bohncke S.J. 2008. [The vegetation during the Younger Dryas (YD) $(<10.9->=10.2$ kyr BP)] // Markova A.K. \& Kolfschoten van T. (eds.). Evolution of the European Ecosystems During the Pleistocene-Holocene Transition (24-8 kyr BP). Moscow: KMK Scientific Press. P.396414 [in Russian with English summary as well as English figure and table captions].

Borodin A.V. 2009. [Identification Guide of Voles Molars of the Urals and Western Siberia (Late Pleistocene Holocene)]. Ekaterinburg: UrO RAN. 100 p. [in Russian]

Estafyev A.A. (ed.). 1994. [Fauna of the European NorthEast of Russia: Mammals. Vol.2. Part 1]. Sankt-Peterburg: Nauka. 280 p. [in Russian]

Golovachov I.B. \& Smirnov N.G. 2009. The Late Pleistocene and Holocene rodents of the Pre-Urals Subarctic // Quaternary International. Vol.201. P.37-42.

Golubeva Ju.V. 2008. [Climate and vegetation of the Holocene on the territory of Komi Republic] // Litosfera. No.2. P.124-132 [in Russian].

Grichuk V.P. 1982. [Vegetation of Europe during Late Pleistocene] // Gerasimov J.P. \& Velichko A.A. (eds.). [Paleogeography of Europe During Last One Hundred Thousand Years]. Moskva: Nauka. P.92-109 [in Russian]. 
Gromov I.M. \& Erbayeva M.A. 1995. [Mammals of USSR Fauna and Adjacent Countries. Lagomorphs and Rodents]. Sankt-Peterburg: ZIN RAN. 522 p. [in Russian]

Gromov I.M. \& Polyakov I.Y. 1977. [Fauna of USSR. Mammals. Vol.3. No.8. Voles Microtinae]. Leningrad: Nauka. 504 p. [in Russian]

Guslitser B.I. \& Pavlov P.Yu. 1988. [Upper Paleolithic site Medvezh'ya Cave] // Savel'eva E. (ed.). [Sites of Stone and Metal Ages of the Northern Preurals. Materials on Archeology of European North-east. No.11]. Syktyvkar: Rotaprint Komi nauchnogo tsentra. P.5-18 [in Russian].

Guslitser B.I., Pavlov P.Yu. \& Panyukova N.N. 1990. [Application of the paleomicrotheriological method for the investigation of Paleolithic locality at the Medvezh'ya Cave] // Kruglikova I.T. (ed.). [The Field Archaeology of Stone Age. Brief Reports of Institute of Archaeology. No.202]. Moskva: Nauka. P.110-114 [in Russian].

Isachenko A.G. 1964a. [Physical maps] // Panev Z.V. (ed.). [Atlas of Komi ASSR]. Moskva: Fabrika No.5 GUGK GGK USSR. P.1-4 [in Russian].

Isachenko A.G. 1964b. [Landscape map and physical zoning] // Panev Z.V. (ed.). [Atlas of Komi ASSR]. Moskva: Fabrika No.5 GUGK GGK USSR. P.57 [in Russian].

Kaakinen A. \& Eronen M. 2000. Holocene pollen stratigraphy indicating climatic and tree line changes derived from a peat section at Ortino, in the Pechora lowland, northern Russia // The Holocene. Vol.10. P.611-620.

Kochev V.A. 1993. [Pleistocene Rodents of Northeastern Europe and Their Stratigraphic Significance]. Sankt-Peterburg: Nauka. 113 p. [in Russian]

Kremenetski C.V., Sulerzhitsky L.D. \& Hantemirov R.M. 1998. Holocene history of the northern range limits of some trees and shrubs in Russia // Arctic and Alpine Research. Vol.30. P.317-333.

Kulik I.L. 1972. [Taiga fauna complex mammals of Eurasia] // Byulleten' Moskovskogo Obshchestva Ispytatelei Prirody. Vol.37. No.4. P.11-24 [in Russian].

Kullman L. 2008. Early postglacial appearance of tree species in northern Scandinavia: review and perspective // Quaternary Science Reviews. Vol.27. P.2467-2472.

Kultti S., Väliranta M., Sarmaja-Korjonen K., Solovieva N., Virtanen T., Kauppila T. \& Eronen M. 2003. Palaeoecological evidence of changes in vegetation and climate during the Holocene in the pre-Polar Urals, Northeast European Russia// Journal of Quaternary Science. Vol.18. P.503-520.

Latalowa M. \& van der Knaap W.O. 2006. Late Quaternary expansion of Norway spruce Picea abies (L.) Karst. in Europe according to pollen data // Quaternary Science Reviews. Vol.25. P.2780-2805.

Nikiforova L.D. 1982. [Dynamics of Holocene biomes in north-east of European part of USSR] // Velichko A.A. (ed.). Razvitie Prirody Territorii SSSR v Pozdnem Pleistotsene i Golotsene. Moskva: Nauka. P.154-162 [in Russian].

Novenko E.Yu., Volkova E.M., Nosova N.B. \& Zuganova I.S. 2009. Late Glacial and Holocene landscape dynamics in the southern taiga zone of East European Plain according to pollen and macrofossil records from the Central Forest State Reserve (Valdai Hills, Russia) // Quaternary International. Vol.207. P.93-103.
Obedkov A.P. 1995. [Komi Republic]. Syktyvkar: Komi respublikansky tsentr po issledovaniyu mezhnatsional'nykh i mezhregional'nykh sotsial'no-ekonomicheskikh problem. 80 p. [in Russian]

Ognev S.I. 1950. [Mammals of USSR and Adjacent countries. Rodents. Vol.7]. Moskva-Leningrad: Izdatel'stvo AN SSSR. 706 p. [in Russian]

Ovchinnikova A.I. 1964. [Climatic maps] // Panev Z.V. (ed.). [Atlas of Komi ASSR]. Moskva. P.19 [in Russian].

Paus A., Svendsen J.I. \& Matiouchkov A. 2003. Late Weichselian (Valdaian) and Holocene vegetation and environmental history of the northern Timan Ridge, European Arctic Russia // Quaternary Science Reviews. Vol.22. P.2285-2302.

Petrov A.N. \& Poroshin E.A. 2005. [Small mammals of southern taiga subzone in the European north-east] // Trudy Komi NC UrO RAN. Syktyvkar: Izdatel'stvo Komi naychnogo tsentra. P.21-29 [in Russian].

Petrov A.N. 1994a. [Collared lemming] // Estafyev A.A. (ed.). [Fauna of European North-East of Russia. Mammals. Vol.2. Part 1]. Sankt-Peterburg: Nauka. P.202212 [in Russian].

Petrov A.N. 1994b. [Ob' (Siberian) lemming] // Estafyev A.A. (ed.). [Fauna of European North-East of Russia. Mammals. Vol.2. Part 1]. Sankt-Peterburg: Nauka. P.213219 [in Russian].

Petrov A.N. 1994c. [Narrow-headed vole] // Estafyev A.A. (ed.). [Fauna of European North-East of Russia. Mammals. Vol.2. Part 1]. Sankt-Peterburg: Nauka. P.236241 [in Russian].

Petrov A.N. 2002. [Small mammals of transformed and intact territories of eastern European tundra] // Roschevsky M.P. (ed.). Vestnik Komi nauchnogo tsentra UrO RAN. No.22. Syktyvkar: Izdatel'stvo Komi naychnogo tsentra. P.48-71 [in Russian].

Polezhaev N.M. 1998. [Polar fox] // Estafyev A.A. (ed.). [Fauna of European North-East of Russia. Mammals. Vol.2. Part 2]. Sankt-Peterburg: Nauka. P.44-61 [in Russian].

Ponomarev D.V. \& Kryazheva I.V. 2011. [Late Pleistocene and Holocene small mammals from localities of Schuger River (the Subpolar Urals)] // Vestnik Instituta Geologii. No.7. P.9-13 [in Russian].

Ponomarev D.V. 2005. [Small mammal remains from Sokoliny Grotto (the Subpolar Urals)] // Materialy IV Vserossiyskogo Soveschanija po Izucheniyu Chetvertichnogo Perioda. Kvarter-2005. Syktyvkar: Geoprint. P.334-336 [in Russian].

Ponomarev D.V. 2006. [Mammalian remains from Sed'yu 1 locality in the Southern Timan] // Struktura, Veschshestvo, Istoriya Litosfery Timano-Severoural'skogo Segmenta. Materialy XV Nauchnoi Konferentsii. Syktyvkar: Geoprint. P.139-142 [in Russian].

Ponomarev D.V. 2009. [Microtheriofauna of Late Glacial and Holocene from the localities of the Middle and Southern Timan] // Geologiya i Mineral'nye Resursy Evropeiskogo Severo-Vostoka Rossii. Materialy XV Geologicheskogo S'ezda Respubliki Komi. Syktyvkar: Geoprint. P.44-48 [in Russian].

Ponomarev D.V., Smirnov N.G., Golovachev I.B., Kourova T.P. \& Kuz'mina E.A. 2005. [Small mammal fauna from 
Pizhma 1 Grotto (the Middle Timan)] // Tsyganko V.S. \& Ponomarev D.V. (eds.). Trudy Instituta Geologii Komi NC UrO RAN. No.117. Syktyvkar: Geoprint. P.86-97 [in Russian].

Ponomarev D., Kolfschoten van T. \& Plicht van der J. 2012. Late Glacial and Holocene small mammals of the Timan Ridge (Komi Republic, Russia) // Quaternary International. http://dx.doi.org/10.1016/j.quaint.2012.04.027.

Pystin A.G. 1994. [Red (Siberian) vole] // Estafyev A.A. (ed.). [Fauna of European North-East of Russia. Mammals. Vol.2. Part 1]. Sankt-Peterburg: Nauka. P.186201 [in Russian].

Rasmussen S.O., Andersen K.K., Svensson A.M., Steffensen J.P., Vinther B.M., Clausen H.B., Siggaard-Andersen M.-L., Johnsen S.J., Larsen L.B., Dahl-Jensen D., Bigler M., Röthlisberger R., Fischer H., Goto-Azuma K., Hansson M.E. \& Ruth U. 2006. A new Greenland ice core chronology for the last glacial termination // Journal of Geophysical Research. Vol.111. D06102.

Reimer P.J., Baillie M.G.L., Bard E., Bayliss A., Beck J.W., Blackwell P.G., Bronk Ramsey C., Buck C.E., Burr G.S., Edwards R.L., Friedrich M., Grootes P.M., Guilderson T.P., Hajdas I., Heaton T.J., Hogg A.G., Hughen K.A., Kaiser K.F., Kromer B., McCormac F.G., Manning S.W., Reimer R.W., Richards D.A., Southon J.R., Talamo S., Turney C.S.M., van der Plicht J. \& Weyhenmeyer C.E. 2009. IntCal09 and Marine09 radiocarbon age calibration curves, $0-50,000$ years cal BP // Radiocarbon. Vol.51. P.1111-1150.

Simakova A.N. \& Puzachenko A.Yu. 2008a. [The vegetation during the Bølling-Allerød Interstadial complex (BAIC) $(<12.4->=10.9$ kyr BP) ] // Markova A.K. \& Kolfschoten van T. (eds.). [Evolution of the European ecosystems during the Pleistocene-Holocene transition (24-8 kyr BP)]. Moscow: KMK Scientific Press. P.369-395 [in Russian with English summaries and figure and table captions].

Simakova A.N. \& Puzachenko A.Yu. 2008b. [The vegetation during the Early Holocene (Preboreal and Boreal periods) (PB-BO) $(<10.2->=8.0 \mathrm{kyr} \mathrm{BP})] / /$ Markova A.K. \& Kolfschoten van T. (eds.). [Evolution of the European ecosystems during the Pleistocene-Holocene transition (24-8 kyr BP)]. Moscow: KMK Scientific Press. P.415-446 [in Russian with English summaries and English figure and table captions].

Smirnov N.G. 1996. [Small mammal diversity of Northern Urals in Late Pleistocene and Holocene] // Smirnov N.G. (ed.). Materialy i Issledovaniya po Istorii Sovremennoi Fauny Urala. Ekaterinburg: Izdatelstvo Ekatrerindurg. P.39-83 [in Russian].

Smirnov N.G. \& Golovachov I.B. 1999. Holocene history of small mammals in the Urals // Benecke N. (ed.). The
Holocene history of the European Vertebrate Fauna Modern Aspects of Research. Archaologie in Eurasien. Vol.6. P.209-221.

Smirnov N.G. \& Sadykova N.Î. 2003. [Sources of errors in faunal reconstructions for Quaternary paleozoology] // Smirnov N.G. (ed.). Chetvertichnaya Paleozoologiya na Urale. Ekaterinburg: Izdatelstvo Ural'skogo Universiteta. P.98-115 [in Russian].

Smirnov N.G. 2003. [Essay on development of Quaternary paleozoology in Ural region] // Smirnov N.G. (ed.). Chetvertichnaya Paleozoologija na Urale. Ekaterinburg: Izdatelstvo Ural'skogo Universiteta. P.24-54 [in Russian].

Smirnov N.G., Andreicheva L.N., Korona O.M., Zinov'ev E.V., Golovachev I.B., Pavlov P.J. \& Hufthammer A.-K. 1999. [Materials to characterize biota of the Pre-Urals Subarctic during the Holocene optimum] // Golovachev I.B. (ed.). Biota Priural'skoi Subarktiki v Pozdnem Pleistotsene i Golotsene. Ekaterinburg: Izdatelstvo Ekaterinburg. P.23-60 [in Russian].

Surova T.G., Troitski L.S. \& Punning J-M. 1975. [Palaeogeography and absolute chronology of the Holocene in the Polar Ural Mountains] // Izvestiya Academii Nauk Estonskoi SSR. Seriya Khimiya and Geologiya. Vol.24. P.152-159 [in Russian].

Turyeva V.V. \& Balibasov V.P. 1982. [On the characteristics of small mammal fauna of northern taiga] // Estafyev A.A. (ed.). Fauna i Ecologiya Ptyts i Mlekopitayucshykh Evropeiskogo Severo-Vostoka SSSR. Syktyvkar: Izdatel'stvo Komi naychnogo tsentra. P.67-73 [in Russian].

Turyeva V.V., Voronin R.N., Estafyev A.A., Novozhilova E.N., Polezhaev N.M. \& Yushkov V.F. 1977. [Distribution and abundance of Timan taiga animals] // Zaboeva I.V. (ed.). Ekologicheskie Issledovaniya Prirodnykh Resursov Severa Nechernozemnoi Zony. Syktyvkar: Rotaprint Komi filiala AN SSSR. P.85-97 [in Russian].

Velichko A.A., Andreev A.A. \& Klimanov V.A. 1997. Climate and vegetation dynamics in the Tundra and Forest Zone during the Late glacial and Holocene // Quaternary International. Vol.41/42. P.71-96.

Velichko A.A., Catto N., Drenova A.N., Klimanov V.A., Kremenetski K.V. \& Nechaev V.P. 2002. Climate changes in East Europe and Siberia at the Late glacial - Holocene transition // Quaternary International. Vol.91. P.75-99.

Voronin R.N. 1995. [Rough-legged buzzard (Buteo lagopus)] // Potapov R.L. (ed.). [Fauna of European northeast of Russia. Birds. Vol.1. Part 1]. Sankt-Peterburg: Nauka. P.77-86 [in Russian].

Wolhfarth B., Lacourse T. \& Bennike O. 2007. Climatic and environmental changes in north-western Russia between 15,000 and 8000 cal yr BP: a review // Quaternary Science Reviews. Vol.26. P.1871-1883. 